\title{
Stress Shifts of English Utterances Made by Indonesian Speakers of English (ISE)
}

\author{
Sukardi Weda ${ }^{1}$ \\ ${ }^{1}$ Faculty of Language and Literature, State University of Makassar, Indonesia \\ Correspondence: Sukardi Weda, Faculty of Language and Literature, State University of Makassar, Kampus \\ UNM Parangtambung Jl. Daeng Tata Makassar 90224, Indonesia. Tel: 62-0411-861-508. E-mail: \\ sukardiweda@yahoo.com
}

Received: May 3, 2012

doi:10.5539/ijel.v2n4p23
Accepted: May 31, 2012 Online Published: June 20, 2012

URL: http://dx.doi.org/10.5539/ijel.v2n4p23

\begin{abstract}
This article examines students' understanding on stress placement in English words. The objectives of the study were to find out: i) the types of English stress shifts made by university students, and ii) the most frequently English stress shifts made by students. There were 27 students participated in this research. They were students of first semester of English Language and Literature State University of Makassar who attended English Phonology subject. This research was qualitative and the instrument used was test. The test was vocabulary list and the students were asked to give primary stress on the word(s). Those words were ranging from one syllable to five syllables.
\end{abstract}

Keywords: phonology, English, stress shifts, Indonesian speakers of English

\section{Introduction}

English is international language and its speakers of approximately 400 million people as the mother tongue and by 700 million people as a second or foreign language (Crystal in Luciana, 2004). This language has unique position in everyday life and has vital role in a wide variety of activities, i.e., economic, political, educational, and socio-cultural domain.

In the international arena, knowing languages other than our native languages means getting lots of benefits. Brown (1994) reveals that becoming bilingual is a way of life. This is because, the majority of textbooks in various disciplines are written in English and it has become international communication in many international activities.

In the ASEAN context, English is already the de facto lingua franca of the ASEAN region, and increasing regional and global trade will only strengthen that (Krasnick in Tickoo, 1995). In our neighboring country of Singapore, English has been believed as the language of economic development, especially in relation with "foreign investment, international trade, and business" (Chew in Dewi, without year).

English has become the first foreign language taught in Indonesia and become a compulsory subject at secondary schools and university level based on the Ministerial Decree No. 096/1967 (Manda, 1998). In the Indonesian context, knowing English means getting a good job, career, and many other advantages. Being able to communicate in English, you can share by others. When you know a language, you can speak and be understood by others who know that language (Fromkin et al., 2007). Fromkin et al., therefore argue that knowing a language means you have the capacity to produce sounds that signify certain meanings and to understand or interpret the sounds produced by others.

One of the things that everybody knows about language is that they have different accents. Languages are pronounced differently by people from different geographical places, from different social classes, of different ages and different educational background (Roach, 1987).

As a second or foreign language in many countries, English presents great difficulties with regards to its language elements (grammar, vocabulary, and pronunciation). The pronunciation of English reveals many problems because the way of pronouncing English and Indonesian language is different. Many researchers, i.e., 
Hamied, Nur, Haryanto in Weda (2009) report that the teaching of English in Indonesia is unsuccessful. One of the causes of the students' low interest and motivation to learn English is its pronunciation.

Indonesian university students had difficulties in identifying the stress for 3 to 7 syllable words (SW), because the students have already leaned a specific stress pattern for the individual words, and they often mistress words with suffixes because they tend to retain the stress for the stem which had been leaned earlier, for example: the word 'circulate which stressed on the first syllable and the word circu'lation which stress on the third syllable.

Furthermore, the writer conducted research in 2009 and the research findings revealed that some informants gave the wrong English stress either on noun or verb category. Thus, it seems that some informants do not control English morphological processes, such as conversion, one word which has two functions, both a noun and a verb. The stresses of these two-word pairs are different. If the word is a noun, the stress should be on the first syllable and its final syllable is reduced, while if the word functions as a verb, the stress is on the second syllable and its initial syllable is reduced.

These findings encouraged the writer to conduct more comprehensive research on stress shifts to students from English Language and Literature Program, Faculty of Language and Literature, State University of Makassar who attended English Phonology subject in 2010.

\subsection{Research Questions}

Such issues as put forward in the previous section give rise to problems specific to the study. The problems are formulated in the following research questions:

1) Which English words undergo stress shifts made by English language and literature students?

2) What are the dominants of English stress shifts made by university students?

\subsection{Scope of the Study}

The study confines its investigation to the shifts of English word stress made by English department students. It is in relation with English phonology, suprasegmental phoneme in particular, the stress shifts are interesting phenomena in language learning made by interlanguage speakers. Hence, the study is not concerned with such issues as error analysis.

\section{Review of Related Literature}

Word stress in English can serve to differentiate meaning that is the stressed syllables in English can differentiate the meaning of two words such as convict as a noun and convict as a verb.

Stress is called a suprasegmental phoneme because it can only occur with the segmental phonemes. Stress is defined as the degree of force used in the production of syllable (Crystal, 1987). This force of emphasis is put on certain words (or certain syllables within words). Ladefoged (1982) defines stress as a suprasegmental feature of utterances; it applies not to individual vowels and consonants but to whole syllables-whatever they might be. A stressed syllable is pronounced with a greater amount of energy than an unstressed syllable.

Stress is a term that we apply to words in isolation which have more than one syllable. It refers to the property that certain syllables carry which makes them stand out from the rest of the word. It seems certain that stressed syllables are made with more effort than unstressed ones; the muscles in the lungs seem to expel air more aggressively than for unstressed syllables (Birjandi, 2005).

Accordingly, McMahon (2002) argues that there are three important factors which combine to signal stress. First, the vowels of stressed syllables are produced with higher fundamental frequency; that is, the vocal folds vibrate more quickly, and this is heard as higher pitch. Secondly, the duration of stressed syllables is greater, and they are perceived as longer. Thirdly, stressed syllables are produced with greater intensity, and are thus heard as louder than adjacent unstressed syllables.

Roach (1987) asks the question, what are the characteristics of stressed syllables that enable us to identify them? It is important to understand that there are two different ways of approaching this question, one being to consider what the speaker does in producing stressed syllables and the other being to consider what characteristics of sound make a syllable seem to a listener to be stressed. In other words, we can study stress from the point of view of production and perception; the two are obviously closely related, but are not identical. The production of stress is generally believed to depend on the speaker using more muscular energy than is used for unstressed syllables. Roach therefore argues that in order to decide on stress placement, it is necessary to make use of some or all of the following information: 
a) Whether the word is morphologically simple, or whether it is complex as a result either of containing one or more affixes (that is, prefixes or suffixes) or of being a compound word.

b) The grammatical category to which the word belongs (noun, verb, adjective, etc.).

c) The number of syllables in the word.

d) The phonological structure of those syllables.

There are five main rules which are useful to be considered in identifying English stress, namely: basic rules, stress in noun-verb pairs, stress with affixes, stress in compound and stress in noun phrase. The examples of number 2.1, 2.2, and 2.3 are taken from Fudge (1988).

\subsection{The Basic Rules}

If the Stress Portion (SP) is monosyllabic, there is no choice of stress placement: The single syllable receives stress.

Examples:

'ship

'eat (+ing)

(un+)'man(+li) (+ness)

If the SP is dissylabic, stress is normally penultimate.

Examples:

'ozon 'Arab 'permit 'import

If the words are verbs, the basic rule is that if the second syllable of the verb contains a long vowel or diphthong, or if it ends with more than one consonant, the second syllable is stressed. Thus:

Examples:

app'ly a'rrive att'ract

If the final syllable contains a short vowel and one (or no final consonant), the first syllable is stressed. Thus:

Examples:

'enter 'equal 'envy

A final syllable is also unstressed if it contains $\vartheta v$.

Examples:

'follow 'borrow

If the SP is trisyllabic or longer, its stress is either penultimate or antepenultimate, depending of a number of factors:

a. If the final syllable is strong, it means the final syllable gets emphasis, so stress falls two syllables back from that syllable, i.e. three syllables from the end of the SP of the word, as in examples below:

'antelope 'cummerbund

b. If the final syllable is weak, it means the final syllable does not get emphasis, then:

i) If the penultimate syllable is strong, then it is stressed as in examples below:

$$
\text { ve'randah spa'ghetti }
$$

ii) If the penultimate syllable is weak, then the syllable before it is stressed, as in examples below:

$$
\text { a'sparagus A'merica }
$$

In verbs, if the last syllable contains a short vowel and ends with not more than one consonant, that syllable will be unstressed and stress will be placed on the penultimate. Thus:

Examples:

en'counter de'termine 
If the final syllable contains a long vowel or diphthong, or ends with more than one consonant, that final syllable will be stressed. Thus:

Examples:

enter'tain

resu'rrect

Again, in nouns, if the final syllable contains a short vowel or diphthong, or if it ends with more than one consonant, that middle syllable will be stressed. Thus:

Examples:

po'tato di'saster

\subsection{Stress in Noun-Verb Pairs}

Certain words exhibit different stress patterns depending on whether they are nouns or verbs. There are several dozen pairs of two syllable words with identical spelling which differ from each other in stress placement, apparently according to word class (noun or verb). Their examples can be seen in Table 1.

Table 1. Noun-Verb pairs

\begin{tabular}{ccc}
\hline Verb & Noun & Notes \\
\hline im'port & 'import & \\
pro’test & 'protest & \\
sub'ject & 'subject & \\
add'ress & 'address & Initial syllable of verbs are reduced, and in \\
pre’sent & 'present & nouns, their final syllables are reduced \\
de’sert & 'desert & \\
ab’sent & 'absent & \\
per'mit & 'permit & \\
etc. & etc. & \\
\hline
\end{tabular}

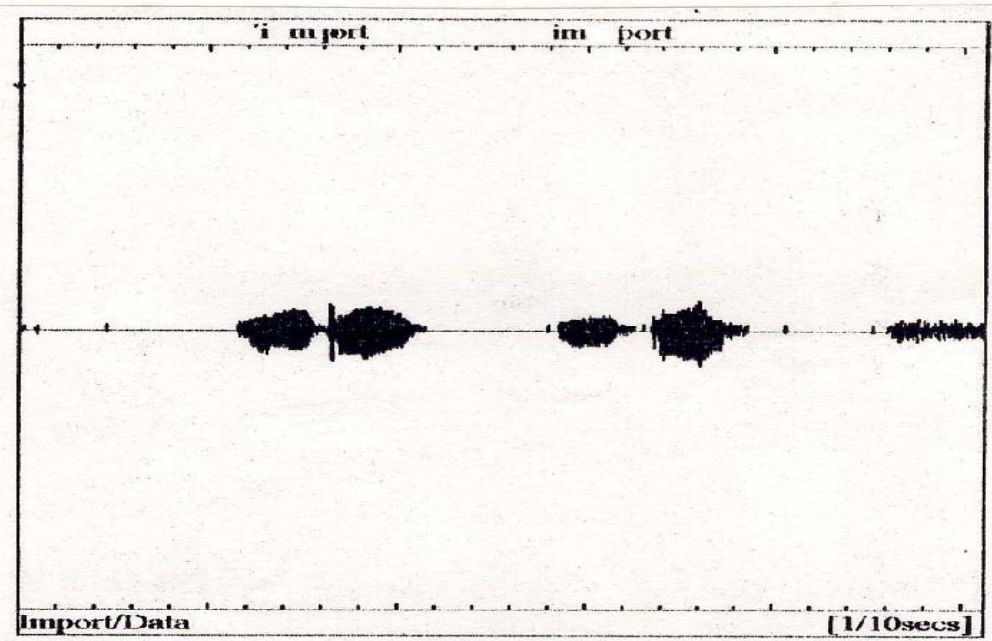

Chart 1. Mingographic tracing of import as a noun and import as a verb 


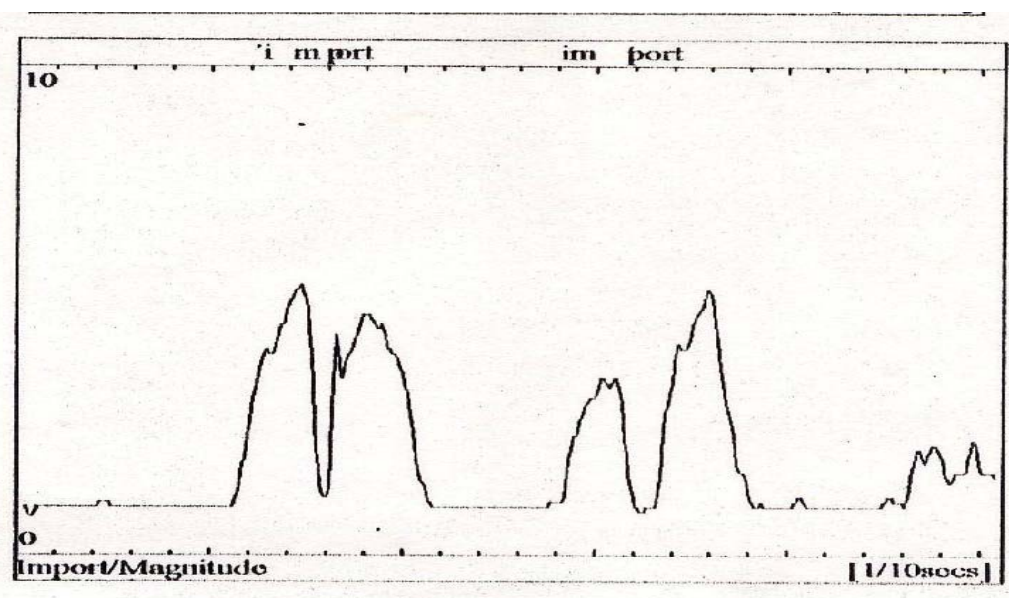

Chart 2. A spectrogram of the word import as a noun and a verb

Note: American accent (Speaker: Barbara Friberg, November 9, 1997 in Weda, 2009)

Furthermore, there are some noun-verb pairs which have three syllables. Their examples are shown in Table 2 below:

Table 2. Noun-Verb pairs

\begin{tabular}{ccc}
\hline Verb & Noun & Notes \\
\hline comple'ment & 'complement & \\
compli'ment & 'compliment & \\
decre'ment & 'decrement & Final syllable of nouns is reduced. Main \\
docu'ment & 'document & (primary) stress is sometimes placed on the \\
imple'ment & 'implement & final syllable in the verbs. \\
incre'ment & 'increment & \\
regi'ment & 'regiment & \\
supple'ment & 'supplement & \\
etc. & etc. & \\
\hline
\end{tabular}

\subsection{Stress with Affixes}

When certain suffixes are attached to free forms (i.e. form which can occur as words in their own right), they leave the stress-pattern unchanged. This kind of suffix is inflectional and it is considered a stress-neutral suffix.

$\begin{array}{lll}\text {-s/-es (plural) } & \text {-s/-es ( } 3^{\text {rd }} \text { person singular) } & \text {-s (possessive) } \\ \text {-ed (past tense, past participle) } & \text {-er (comparative) } & \text {-en (past participle) } \\ \text {-est (superlative) } & \text {-ing (present participle, gerund) } & \end{array}$

Some derivational suffixes also behave in this way; some are always stress-neutral (they do not influence the stress placement). The following is intended as neutral-derivational suffixes:

$\begin{array}{lll}\text {-acy } & \text { 'accurate } & \text { 'accuracy } \\ \text {-age } & \text { 'anchor } & \text { 'anchorage } \\ \text {-ary } & \text { 'budget } & \text { 'budgetary } \\ \text {-ness } & \text { 'manager } & \text { 'manageress } \\ \text {-ious } & \text { 'prestige } & \text { 'prestigious } \\ \text {-ment } & \text { disa'gree } & \text { disa'greement } \\ \text {-ness } & \text { po'lite } & \text { po'liteness }\end{array}$

etc. 
On the other hand, there are some suffixes that influence stress in the stem, and the primary stress is on the last syllable of the stem. These suffixes are seen in the following.

Examples:

$\begin{array}{lll}\text {-eous } & \text { ad'vantage } & \text { advan'tageous } \\ \text {-graphy } & \text { 'photo } & \text { pho'tography } \\ \text {-ivity } & \text { 'object } & \text { objec'tivity }\end{array}$

etc.

Certain prefixes, like stress-neutral suffixes, are automatically discounted when the placement of main stress is being calculated: main stress can not possibly fall on them. They are not part of the SP of the word. Thus the word "proper" and "probable", if they are added with prefixes (im+proper, im+probable), the prefixes do not influence the stress placement or they are stress-neutral prefixes.

Examples:

$\begin{array}{ll}\text { 'proper } & \text { im'proper } \\ \text { 'probable } & \text { im'probable } \\ \text { etc. } & \end{array}$

\subsection{Stress in Compound and Noun Phrase}

For noun phrase and compound word, as far as stress is concerned, the question is quite simple. When is primary stress placed on the first word and when on the second? The answer is, if it is a noun phrase (its first element is adjective), the stress goes on the second element. On the other hand, if it is compound (its first element is a noun), so the stress goes on the first element. Detailed examples are revealed below.

$\begin{array}{ll}\text { Noun Phrases: } & \text { Compounds: } \\ \text { green 'house } & \text { 'greenhouse } \\ \text { light 'ship } & \text { 'lightship } \\ \text { cross 'word } & \text { 'crossword } \\ \text { loud 'speaker } & \text { 'loudspeaker }\end{array}$

etc.

\section{Research Method}

This research employed qualitative approach which supported by descriptive statistics. The data in this research were obtained from the first semester students of English Language and Literature, Faculty of Language and Literature, State University of Makassar. The respondents of this research were 27 students who attended English Phonology subject and all respondents are Indonesian. The respondents were given test (vocabulary list) as the instruments of this research to obtain information of English words undergo stress shifts made by English department students.

The data were collected by asking the students to give stress (') above the syllable of the word(s) in the vocabulary list. Mingographic tracings for the reference are presented as examples which graphically show stress variation. The method of obtaining the mingographic tracings was that a native speaker of American English (AE) recorded words using Computer CECIL Program. The spectrogram of the word was shown on the computer screen, and then the spectrogram was printed to get mingographic tracing. The CECIL Program was used to record the words or phrases. This program then produces various types of graphs showing the raw data signal, the changes in quality, the loudness, and the frequency. These graphs are used to interpret the sounds recorded and aid the researcher in identifying difficult parts of the sounds or pitch variances. Several mingographic tracings have been presented using the output from the CECIL Program. Mingographic tracings of the words: import as a verb and import as a noun as revealed in the review of literature as examples. The most significant source for actual English stress pattern was Gimson (1985) and New Webster's Dictionary.

\section{Finding and Discussion}

This chapter consists of data analysis and discussion. In the data analysis, the kinds of analysis are presented; those are tabulation and percentage of stress shifts of monosyllabic and polysyllabic words. 
Discussion therefore provides the answers of the research questions as presented in chapter one. The stress shifts are revealed according to their frequency in the Table 3 below.

\subsection{Analysis}

Table 3 below shows the frequency and percentage of stress shifts made by students at the English language and literature, State University of Makassar in 2010/2011 academic year. The Table is therefore followed by explanation.

Table 3. Stress shift frequency

\begin{tabular}{|c|c|c|}
\hline Monosyllabic & Frequency & Percentage (\%) \\
\hline ship & 19 & 70.37 \\
\hline eat & 12 & 44.44 \\
\hline Disyllabic & Frequency & Percentage (\%) \\
\hline ozon & 17 & 62.96 \\
\hline permit & 18 & 66.66 \\
\hline apply & 14 & 51.85 \\
\hline attract & 9 & 33.33 \\
\hline arrive & 10 & 37.03 \\
\hline enter & 14 & 51.85 \\
\hline envy & 19 & 70.37 \\
\hline follow & 7 & 25.92 \\
\hline borrow & 7 & 25.92 \\
\hline Trisyllabic or Longer & Frequency & Percentage (\%) \\
\hline antelope & 21 & 77.77 \\
\hline cummerbund & 23 & 85.18 \\
\hline verandah & 22 & 81.48 \\
\hline spaghetti & 15 & 55.55 \\
\hline asparagus & 15 & 55.55 \\
\hline America & 17 & 62.96 \\
\hline encounter & 17 & 62.96 \\
\hline determine & 23 & 85.18 \\
\hline entertain & 22 & 81.48 \\
\hline resurrect & 10 & 37.03 \\
\hline potato & 14 & 51.85 \\
\hline disaster & 17 & 62.96 \\
\hline Derivational Suffixes & Frequency & Percentage (\%) \\
\hline comfortable & 19 & 70.37 \\
\hline interpretable & 26 & 96.29 \\
\hline accuracy & 10 & 37.03 \\
\hline budgetary & 22 & 81.48 \\
\hline commander & 23 & 85.18 \\
\hline purposefull & 14 & 51.85 \\
\hline childhood & 21 & 77.77 \\
\hline prestigious & 6 & 22.22 \\
\hline imperialism & 17 & 62.96 \\
\hline
\end{tabular}




\begin{tabular}{ccc}
\hline modernist & 22 & 81.48 \\
accomplishment & 19 & 70.37 \\
advertisement & 17 & 62.96 \\
politeness & 19 & 70.37 \\
contradictory & 16 & 59.25 \\
advantageous & 22 & 81.48 \\
European & 21 & 77.77 \\
photography & 20 & 74.07 \\
radiography & 21 & 77.77 \\
athletics & 26 & 96.29 \\
productivity & 14 & 51.85 \\
universal & 26 & 96.29 \\
\hline Stress With Prefixes & Frequency & Percentage (\%) \\
\hline improper & 7 & 25.92 \\
improbable & 9 & 33.33 \\
uncomfortable & 10 & 37.03 \\
unfair & 5 & 18.51 \\
\hline
\end{tabular}

Of the total 2 monosyllabic words, "ship” and "eat”, there are 19 or 70.37 percent of stress shifts for word "ship" and there are 14 or 44.44 percent of stress shifts for word "eat. Of the total 9 dissyllabic words, the highest stress shift is placed by the word "envy" with 19 stress shifts or 70.37 followed by word "permit" with 18 stress shift (66.66 percent) and word "ozon" with 17 or 62.96 percent of stress shifts.

Of the total 12 trysillabic words or longer, the word "cummerbund" and "determine" have the highest of stress shifts, that is 23 shifts or 85.18 percent followed by word "verandah" and "entertain" with 22 or 81.48 stress shifts.

Of the total 21 derivational suffixes, there are three words place the highest frequency of stress shifts. Those words are "interpretable", "athletics", and "universal" with 26 or 96.29 percent of stress shift of each word. The second position is placed by the word "commander" with 23 or 85.18 percent of stress shifts. The third position is placed by word "advantageous" with 22 or 81.48 shifts. In derivational suffixes, almost all words undergo change above 50 percent. This means that the students have difficulties in identifying the correct stress for words with suffixes.

Of the total 4 words with prefixes, none of words undergo change above 40 percent. This means that the students do not find difficulties in identifying stress for the words with prefixes. May be because, they have known the stem for the word.

\subsection{Discussion}

The discussion is intended to give an explanation for the research questions mentioned above.

1) Kinds of Stress Shifts in English Made by Students

This research found that most of the students could not identify word stress, monosyllabic, dissyllabic, trisyllabic word, words with suffixes or words with prefixes. The research findings reveal that the highest stress shift in monosyllabic word is the word "ship". In dissyllabic words, the word "envy", "permit", and "ozon", have the highest stress shifts.

In trisyllabic words, the highest stress shifts paced by word "cummerbund”, “determine”, "verandah”, and "entertain".

In derivational word with suffixes, there are three words which place the highest frequency of stress shifts. Those words are "interpretable", "athletics", and "universal".

2) The Highest Frequency of English Stress Made by Students

The highest frequency of English stress made by students is words with suffixes, followed by trisyllabic, dissyllabic, and monosyllabic word, while words with prefixes are minor one. 
4.3 Kinds of Stress Shifts in English Utterances Made by Indonesian Speakers of English (ISE)

The kinds of deviant stress shifts made by ISE are as follows:

1) Monosyllabic Words

If the stressable portion monosyllabic word, there is no choice of stress placement. The single syllable receives stress. But what is actually found in the data was that some informants made stress shift in this category.

Example:

- Wrong stress: ship'

- Correct stress: ‘ship

2) Dissyllabic Words

Stress shifts to two-syllable words which contain a short vowel and a (or no) final consonant to its syllables, here the first syllable should be stressed. But what is actually found in the data was that some informants stressed the final syllable.

Examples:

- Wrong stress: en'vy

$$
\begin{aligned}
& \text { per'mit } \\
& \text { o'zon }
\end{aligned}
$$

- Correct stress: ‘envy

'permit

'ozon

3) Trisyllabic Words

If the stressable portion is trisyllabic or longer, its stress is either penultimate or antepenultimate, depending on a number of factors. In the sample data, testees who mistressed trisyllabic words, they stressed wrong syllable (see basic rules on page 3).

Examples:

- Wrong stress: cummer'bund

$$
\begin{aligned}
& \text { deter'mine } \\
& \text { veran'dah } \\
& \text { 'entertain }
\end{aligned}
$$

- Correct stress: 'cummerbund

dete'mine

ve'randah

enter'tain

\section{Conclusion}

Based on the results of the data analysis as mentioned before, it can be concluded that:

1) The words that undergo shift are monosyllabic, dissyllabic words, trisyllabic words, and words with prefixes, while students are competent to identify stress for words with suffixes. In the test, some informants gave the wrong English stress in a variety of syllabic.

2) The highest frequency of English stress shits made by students was monosyllabic, dissyllabic, and trisyllabic words and words with prefixes. It seems that some informants do not control English morphological process, such as prefixes and suffixes. They tend to retain the stress for the stem in word with suffixes which had been learned earlier, but the students can put the correct stress for words with prefixes.

\section{Suggestions}

It is suggested that researchers consider the following suggestions for further researches focus on related topics under the umbrella of English linguistics. 
1) The present study presents a description of the stress of English utterances made by students of English Language and Literature, Faculty of Language and Literature, State University of Makassar. The scope of this study is limited to phonology studies, that is, English stress shifts. If we refer to linguistics, there are four branches of linguistics (phonology, morphology, syntax, and semantics). Other researchers could do research on other parts of the study, i.e., morphology, syntax, and semantics. Such further research could enrich linguistic studies especially in English as a foreign language (EFL) in Indonesia.

2) Stress as a prosodic (suprasegmental) feature should be taught at secondary school to university or to other people beginning to learn EFL. This is so that the differences between stress in English and in Bahasa Indonesia could be effectively taught.

3) Words in English have more complete stress patterns and a number of rules governing these patterns must be controlled by learners or people who learn EFL.

\section{References}

Birjandi, Parviz. (2005). An Introduction to Phonetics. Tehran: Zabankadeh Publications.

Brown, H. Douglas. (1994). Principles of language Learning and Teaching. New Jersey: Prentice Hall Regents.

Crystal, David. (1987). A Dictionary of Linguistics and Phonetics. Oxford: Basil Blackwell Ltd.

Dewi, Anita Sartika. (Without Year). What the Young Generation Perceives in EIL Era: A Qualitative Study of Yogyakarta University Students. Selected Papers in English Language Teaching. Jakarta: RELO-Embassy of United States in Jakarta, Indonesia.

Fromkin, Victoria \& Rodman, Robert. (2007). An Introduction to Language. Boston: Thomson Wadsworth.

Fudge, Elaine. (1988). Variation in Interlanguage. London: Edward Arnold.

Gimson, A. C. (1985). An Introduction to the Pronunciation of English. Hongkong: Wing King Tong Co. Ltd.

Gimson, A. C. (1987). A Practical Course of English Pronunciation. Hongkong: Wing King Tong Co. Ltd.

Hunt, Geoffrey. (1995). Interpreting CECIL: Gathering and Interpreting Acoustic Phonetic Data. Waxhaw, NC: Summer Institute of Linguistics (SIL).

Krasnick, Harry. (1995). The Role of Linguaculture and Intercultural Communication in ASEAN in the Year 2020: Prospects and Predictions. In Tickoo Makhan L. (Ed.), Language and Culture in Multilingual Societies: Viewpoints and Visions. Singapore: RELC.

Ladefoged, Peter. (1982). A Course in Phonetics. New York: Harcoutt, Brace, Jovanovich.

Luciana. (2004). Communicative Competence: Revisited. Proceeding on Conference on English Studies (CONEST), 1. Jakarta: Pusat Kajian Bahasa dan Budaya, Unika Atmajaya.

Manda, M. L. (1998). Dictogloss: Its Effects on the Learner's Proficiency in English as a Foreign Language. Dissertation. Makassar: Graduate Program Hasanuddin University.

McMahon, April. (2002). An Introduction to English Phonology. Edinburgh: Edinburgh University Press Ltd.

Roach, Peter. (1987). English Phonetics and Phonology: A Practical Course. Cambridge: Cambridge University Press.

Weda, Sukardi. (1998). Interlanguage Phonology: Stress Shifts of English Utterances Made By Indonesian University Students. Unpublished Thesis. Makassar: Graduate Program, Hasanuddin University.

Weda, Sukardi. (2009). English Learning Strategies. Makassar: Lembaga Pusat Pengembangan Masyarakat Marginal.

Weda, Sukardi. (2009). Interlanguage Phonology: Stress Shifts of English Utterances Made by Indonesian University Students. Proceeding, Konferensi Internasional Masyarakat Linguistik Indonesia (KIMLI). Batu Malang: Universitas Negeri Malang. 